\title{
FEATURES OF THE MAXIMUM WATER FLOWS OF THE ARPA RIVER UNDER MODERN CONDITIONS
}

\author{
Varduhi Margaryan ${ }^{1, *}$, Levon Azizyan ${ }^{2}$, Amalya Misakyan² $^{2}$ Ekaterina Gaidukova ${ }^{3}$, Gennady Tsibul'skii $^{4}$, \\ Ksenia Raevich ${ }^{4}$ \\ ${ }^{1}$ Yerevan State University, Department of Physical Geography and Hydrometeorology, Faculty of Geography and \\ Geology, 0025, Alek Manoukian 1 st., Yerevan, Armenia \\ ${ }^{2}$ Hydrometeorology and Monitoring Center SNCO with Ministry of Environment of the Republic of Armenia, Yerevan, \\ Armenia \\ ${ }^{3}$ Russian State Hydrometeorological University, Saint-Petersburg, Russia \\ ${ }^{4}$ Siberian Federal University, Institute of Space and Information Technologies, Chair of Systems of Artificial \\ Intelligence, 660074 Kirenskogo St. 26, Krasnoyarsk, Russia
}

\begin{abstract}
The paper discusses the main regularities of the peak flood discharge distribution in modern conditions, using actual data of Hydrometeorology and Monitoring Center SNCO with Ministry of Environment of the Republic of Armenia on the peak flood discharge of the river Arpa.
\end{abstract}

\section{Introduction}

Water management planning, assessment of water resources, and construction design of hydraulic structures should take account of the peculiarities of the water regime formation in rivers, water content, maximum and minimum runoff, which contributes to the relevance of alternative methodological approaches to assessing the extreme characteristics of runoff, in particular, the peak flood discharge of unexplored rivers [9]. The maximum water discharge during the flood period is one of the most important characteristics of this phase of the water regime. Meaning maximum flow rate is very important for economic activities, as it determines the possibility of flooding adjacent to the watercourse territories [4]. As one of the most common natural phenomena, floods can bring both risks and benefits for human beings. They can pose a risk of inundation to a human habitat but can also be utilized as a resource with hydraulic engineering. Improving the knowledge of flood characteristics is the basis and premise of improving water resources management and ecological environmental protection [17]. Determination of the peak river water discharge is a mandatory stage of engineering surveys for the construction of all water management systems, bridges, pipeline crossings and a number of other structures [13]. Significant influence of anthropogenic factors (reservoirs) on the maximum flow of the spring flood allow us to estimate the changes of values of the maximum flow in number [1].

That is, the role of knowledge about peak discharge is great, especially from the point of view of the hydraulic structure design and operation, and implementation of measures to prevent the damage caused. Peak discharge rates are one of the most important characteristics of the flood phase of the water regime.

The purpose of this article is to analyze and assessing the features of peak discharge distribution in the current conditions of the Arpa river.

Studying the issues of space-time distribution, formation and forecasting of maximum water discharge in rivers At one time, many Armenian scientists-hydrologists were engaged in Armenia, in in particular, M.V. Shahinyan [14], V.G. Margaryan and others [7-8], A.E. Misakyan and others [10], based on the results of many years of research, monographs $[3,16]$ etc.

\section{Study areas, Data and Methods}

The Arpa River is a large left tributary of the river. Araksa: along its length it the fourth in the Republic of Armenia (RA) [8]. The length of the Arpa River is $128 \mathrm{~km}$, total the catchment area is $2630 \mathrm{~km}^{2}$, but on the territory of the Republic of Armenia there are $92 \mathrm{~km}$ and $2080 \mathrm{~km}^{2}$, respectively (of which $1880 \mathrm{~km}^{2}$ is the catchment area post of Areni). The Arpa River originates from the northwest slope Syunik highlands from a height of $3260 \mathrm{~m}$ (fig. 1). The estuary is at a height $960 \mathrm{~m}$. The river in the upper and middle reaches, as well as its tributaries, have features

*Corresponding author: vmargaryan@ysu.am 
inherent in mountain rivers: pass through large gorges and valleys cut by tributaries and ravines. Average slope of the catchment the basin of the Jermuk post is $188 \%$ (table 1). The studied territory, the average height of the catchment area at water measuring posts is in range from 2110 to $2790 \mathrm{~m}$, and the catchment area - from 199 to 1880 $\mathrm{km}^{2}$.

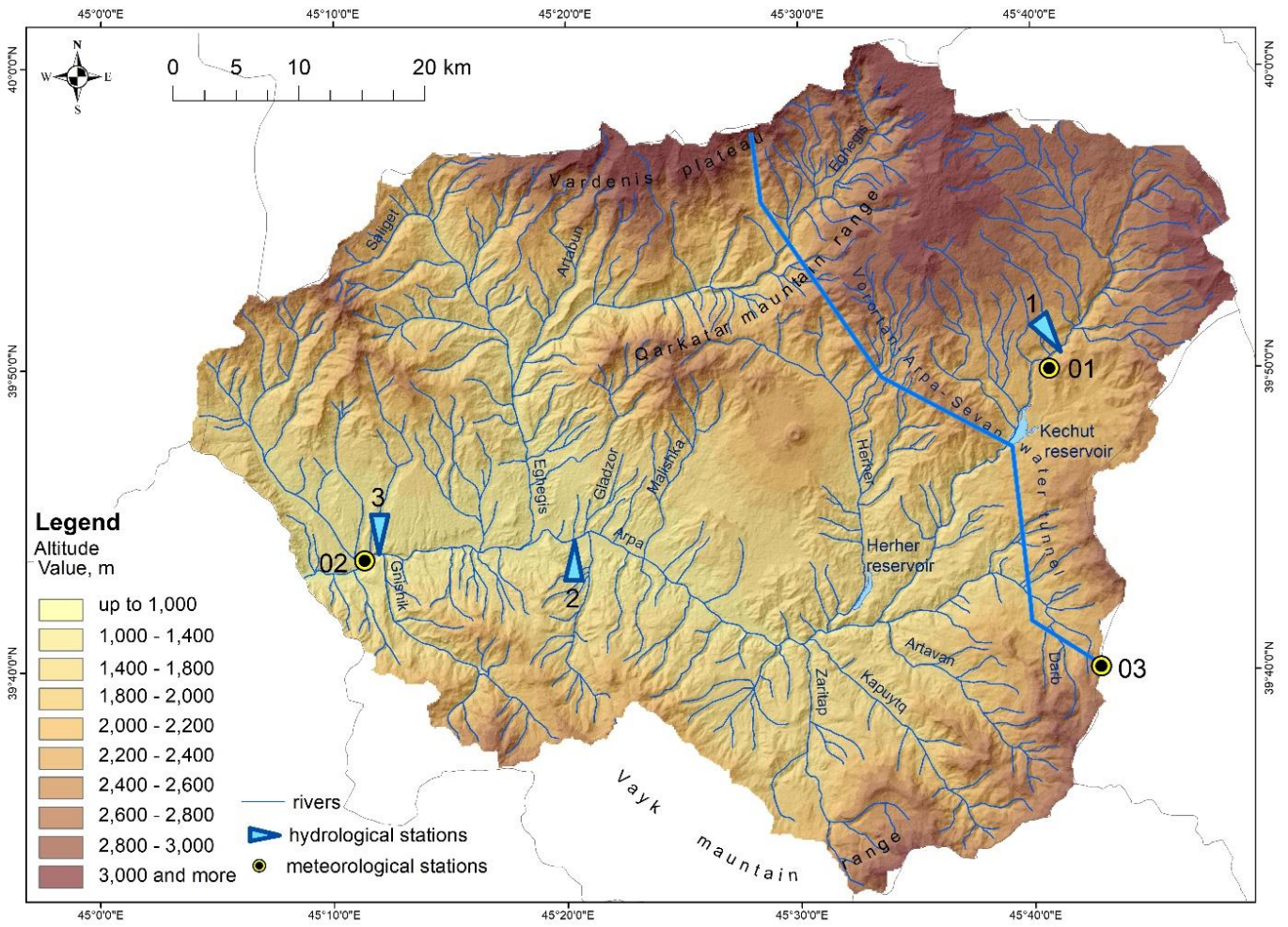

Fig. 1. Location of hydrological posts in the river Arpa and meteorological stations in the there basin hydrological posts (p.): 1 - r. Arpa - p. Jermuk, 2 -r. Arpa - p. Ekhegnadzor, 3 - r. Arpa - p. Areni; meteorological stations: 01 - Jermuk, 2 - Areni, 03 - Vorotan Pass.

The basin is composed mainly of volcanic rocks. The highest parts of the mountains are composed of andesitebasalts, below are widespread received andesites, tuffs, tuff breccias and other rocks. Below p. Areni Arpa goes into the area of foothills, where the volcanic stratum is replaced dislocated sedimentary rocks - limestones, sandstones, schists and quartzites of the Paleozoic. Gradually lowering towards the south and southeast, the foothills pass into the Priaraksa lowland $(800-900 \mathrm{~m})$ [11].

Table 1. Main hydrometric and hydrological characteristics of the Arpa River basin rivers and their catchments [8]

\begin{tabular}{|c|c|c|c|c|c|c|c|c|}
\hline \multirow{2}{*}{ № } & \multirow{2}{*}{ River - post } & \multirow{2}{*}{ 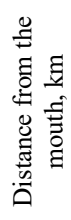 } & \multicolumn{2}{|c|}{ Slope of river, $\%$} & \multicolumn{3}{|c|}{$\begin{array}{l}\text { Main characteristics } \\
\text { of the catchment }\end{array}$} & \multirow{2}{*}{$\begin{array}{c}\text { Average } \\
\text { annual } \\
\text { water flow, } \\
\mathrm{m}^{3 / \mathrm{s}}\end{array}$} \\
\hline & & & $\begin{array}{l}\text { from the } \\
\text { most distant } \\
\text { point }\end{array}$ & $\begin{array}{l}\text { weignted } \\
\text { mean from } \\
\text { the most } \\
\text { distant poin }\end{array}$ & $\begin{array}{l}\text { area, } \\
\mathrm{km}^{2}\end{array}$ & $\begin{array}{l}\text { average } \\
\text { height, } \mathrm{m}\end{array}$ & $\begin{array}{l}\text { average } \\
\text { slope, \%o }\end{array}$ & \\
\hline 1 & Arpa-Jermuk & 105 & 52 & 48 & 199 & 2790 & 188 & 5.15 \\
\hline 2 & Arpa - Ekhegnadzor & 56 & 30 & 22 & 1220 & 2140 & - & 7.75 \\
\hline 3 & Arpa-Areni & 40 & 26 & 20 & 1880 & 2110 & - & 13.6 \\
\hline
\end{tabular}

The waters of the river are used for irrigation and hydropower purposes. A significant part of its waters through the Vorotan-Arpa-Sevan tunnel flows into the lake. Sevan. The long-term average water consumption at the closing 
post of Areni is $13.6 \mathrm{~m}^{3} / \mathrm{s}$ for the period 1981-2019 (table 1).

The main role in the formation of the maximum flow rates of the river. Arpa plays the amount of snow storage and heat inflow. Amount and date of occurrence maximum water consumption is associated with the amount of snow reserves, the intensity of the inflow of warm air and precipitation. Average annual air temperature according to the meteorological station is in range from 3.1 to $12.9^{\circ} \mathrm{C}$, annual precipitation - in the range from 374 up to $764 \mathrm{~mm}$ (table 2). The maximum air temperature can be up to $+42.6{ }^{\circ} \mathrm{C}$, and the minimum - up to $-30.0{ }^{\circ} \mathrm{C}$. Relative humidity ranges from 60 to $80 \%$, and the lack of air humidity - from 2.2 to $9.3 \mathrm{hPa}$.

Table 2. Average long-term actual values of meteorological characteristics for the period 1981-2019 at meteorological stations of the Arpa River basin

\begin{tabular}{|l|l|c|c|c|}
\hline \multicolumn{2}{|c|}{ Meteorological stations } & Jermuk & Areni & Vorotan Pass \\
\hline \multirow{3}{*}{$\begin{array}{l}\text { Air temperature, } \\
{ }^{\circ} \mathrm{C}\end{array}$} & average & 5.1 & 12.9 & 3.1 \\
\cline { 2 - 5 } & absolute maximum & 33.8 & 42.6 & 30.2 \\
\cline { 2 - 5 } & absolute minimum & -30.0 & -22.4 & -27.5 \\
\hline \multirow{2}{*}{ Atmospheric precipitation amount, mm } & 764 & 374 & 619 \\
\hline \multirow{2}{*}{ Humidity } & relative, \% & 71 & 60 & 80 \\
\cline { 2 - 5 } & deficit, $\mathrm{hPa}$ & 3.81 & 9.32 & 2.24 \\
\hline
\end{tabular}

The theoretical and informational background were the results presented in the work $[2,5-6,12,15]$. Actual observations of Hydrometeorology and Monitoring Center SNCO with Ministry of Environment of the Republic of Armenia for the years 1957-2020 were used as the initial material. The peak discharge was studied in those section lines of the rivers that are located directly on the Arpa river (fig. 1). Actual observations of the peak discharge were carried out since the early 30s of the 20th century in Yeghegnadzor (about $1075 \mathrm{~m}$ ) and Areni (about $999 \mathrm{~m}$ ) section lines located in the lower reaches of the Arpa river, and since 1957 in Jermuk section line, which is located upstream (about $2034 \mathrm{~m}$ ). Therefore, for the purpose of comparison and referencing, features of peak discharge of the Arpa river in modern conditions were studied in the work for the period of 1957-2020. However, in 1981, operation of the Kechut reservoir started, which was built on the Arpa river, downstream from Jermuk section. Accordingly, to assess the impact of the reservoir on the peak discharge in Yeghegnadzor and Areni section lines of the Arpa river, two periods were distinguished: before the reservoir operation (1957-1980) and after the operation (1981-2020).

This study applies the method of mathematical and statistical analysis, the method of comparison and referencing, extrapolation and correlation, and complex geographic-graphical-hydrometeorological analysis.

\section{Results and discussion}

Due to the variety of natural conditions of the studied area the absolute maximum flow rates of the spring flood are distributed very unevenly (table 3), but the leading role belongs to climate in combination with the features of the relief, soil and vegetation cover and geological and hydrogeological structure of river catchments. At volume, conditions for the formation of the maximum water consumption from year to year vary depending on meteorological factors. Absolute maximum flow rates of the river. Arpa range from $91 \mathrm{~m}^{3} / \mathrm{s}$ to $199 \mathrm{~m}^{3} / \mathrm{s}$ for the period $1980-2020$.

In the study area, the absolute peak water discharge occurs mainly during the spring flood. In the period from 1957 to 2020, the absolute peak water discharge in Jermuk section line of the Arpa river was observed during the spring flood in all years, while in Yeghegnadzor and Areni section lines of the Arpa river is was observed in $1.6 \%$ of cases. During the flood period along the rivers of the river basin. Arpa on average passes about 55-62\% of the total runoff per year. Average volume of spring flood r. Arpa varies widely: from 95.5 million $\mathrm{m}^{3}$ (r. Arpa - p. Jermuk) up to 277 million $\mathrm{m}^{3}$ (r. Arpa - p. Areni). Spring flood looks like a well-defined wave formed by melted snow, rain and groundwater. 
Table 3. The main long-term characteristics of the peak flood discharge of the Arpa river for the periods before and after operation of the reservoir

\begin{tabular}{|c|c|c|c|c|c|c|c|c|c|}
\hline \multirow[b]{3}{*}{ River - post } & \multirow{2}{*}{\multicolumn{2}{|c|}{ Observation period }} & \multicolumn{7}{|c|}{ Long-term run-off characteristics } \\
\hline & & & \multicolumn{3}{|c|}{$\begin{array}{l}\text { Maximum for the observation } \\
\text { period and the year }\end{array}$} & \multicolumn{4}{|c|}{ Over a long period } \\
\hline & 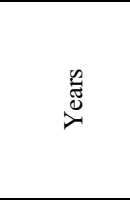 & 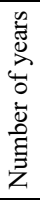 & 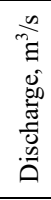 & 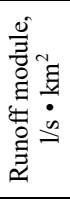 & 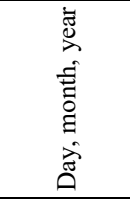 & 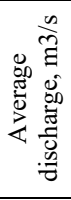 & 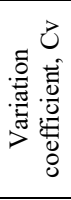 & 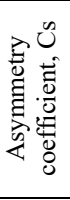 & $\mathrm{Cs} / \mathrm{Cv}$ \\
\hline Arpa - Jermuk & $1957-2020$ & 64 & 91,0 & 457 & $17 / 05 / 1983$ & 46.0 & 0.40 & -0.30 & -0.75 \\
\hline \multirow{3}{*}{ Arpa - Yeghegnadzor } & $1957-1980$ & 24 & 244 & 200 & $29 / 04 / 1969$ & 106 & 0.38 & 1.72 & 4.53 \\
\hline & $1981-2020$ & 40 & 131 & 107 & 29/04/1997 & 64.6 & 0.40 & 0.56 & 1.40 \\
\hline & difference & & 113 & 93 & & 41.4 & & & \\
\hline \multirow{3}{*}{ Arpa - Areni } & $1957-1980$ & 24 & 340 & 181 & $01 / 04 / 1969$ & 168 & 0.43 & 1.05 & 2.44 \\
\hline & $1981-2020$ & 40 & 199 & 106 & $18 / 04 / 1988$ & 115 & 0.40 & 0.04 & 0.10 \\
\hline & difference & & 141 & 75 & & 53 & & & \\
\hline
\end{tabular}

Downstream of the Arpa river, the peak discharge values increase and reach large values in the outlet (таble 3). The highest peak discharge, observed on 18 April 1988 in Areni settlement section line, was $199 \mathrm{~m}^{3} / \mathrm{s}$, and before the construction of Kechut reservoir, on 1 April 1969, the river passed $340 \mathrm{~m}^{3} / \mathrm{s}$ of water. After construction of the reservoir, the flow of the river was regulated. As a result, for the period of 1981-2020 there was a decrease in the main characteristics of the peak spring flow discharge as compared with the period of 1957-1980 (fig. 2). So, the Danjiangkou Reservoir has changed the flood characteristics to a great extent both of seasonal or annual floods, and the mean degree of the alteration is about $19 \%$ [17].

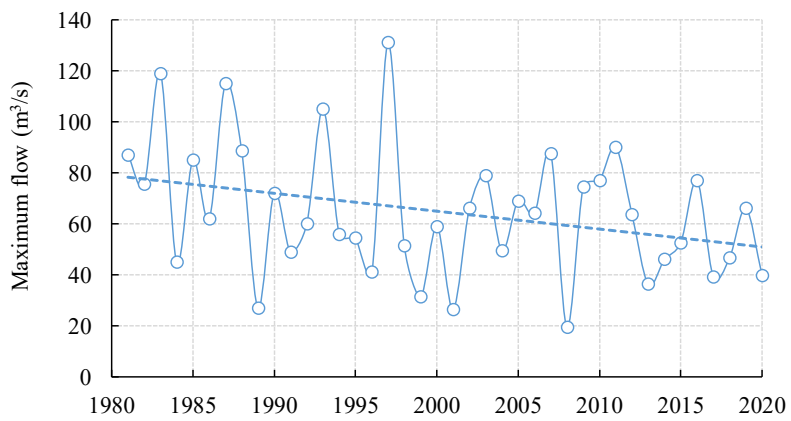

Fig. 2. Dynamics of changes in maximum flow on Arpa river - Yeghegnadzor post

Table 3 shows that the variation coefficient $(\mathrm{Cv})$ of the absolute peak discharge of the Arpa rivers does not exceed 0.50 for the entire period under discussion and changes within a small range from 0.46 to 0.40 . Such variation values are rather small for absolute peak flow discharge rates. That is, it can be assumed that the absolute peak discharges of the Arpa rivers are quite stable and have relatively low risk values. Unlike the variation coefficient, the series asymmetry coefficient (Cs) has large values varying from 1.05 to 1.72 for the period 1957-1980 and from 0.04 to 0.56 . The asymmetry coefficient shows distribution of the series members in relation to the central member of the series, if the series is presented in decreasing or increasing order. 


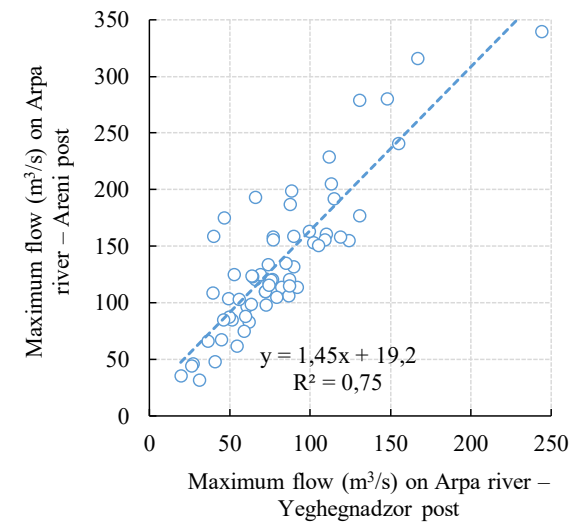

Fig. 3. Correlation between the absolute maximum flow $\left(\mathrm{m}^{3} / \mathrm{s}\right)$ values on Arpa river - Yeghegnadzor post and Arpa river - Areni post

A correlation is noted between the values of the absolute peak discharge values for the flood period (IV-VI) on the Arpa rivers in Areni and Yeghegnadzor section lines. A dependence of this kind can be used to calculate and forecast the maximum runoff of the spring flood (Fig. 3).

\section{Conclusions}

Thus, the absolute maximum flow occurs during the spring flood, in Jermuk section line of the Arpa river. The absolute maximum flow values were observed during the spring flood in all years in the period from 1957 to 2020 . In Yeghegnadzor and Areni section lines they were observed in $1.6 \%$ of cases.

Downstream of the Arpa river, the maximum flow values increase to reach high values in Areni outlet.

In the period of 1981-2020, there is a decrease in the main characteristics of the peak flood discharge as compared with the period of 1957-1980.

The series variation coefficient of the absolute peak discharge values varies within a small range, from 0.46 to 0.40 ; the asymmetry coefficient varies in a relatively large range of 1.05 to 1.72 for the period of 1957-1980 for Yeghegnadzor and Areni section lines of the Arpa river.

A correlation has been revealed between the absolute peak discharge values for the flood period on the Arpa river in Yeghegnadzor and Areni section lines, which can be used for calculating and forecasting the peak flood run-off.

Financing. This work was supported by the RA Science Committee and Russian Foundation for Basic Research $(R F)$ in the frames of the joint research project SCS 20RF-039 Short-term probabilistic forecast of river flow during the spring flood and RFBR № 20-55-05006 20 accordingly.

\section{References}

1. Arystambekova D., Jussupbekov D., Skakova A., Kujibayeva G., Mamirova K. Assessment of Changes in the Maximum Flow of Kazakhstan Plain Rivers // Journal of Ecological Engineering Vol. 20(5), 2019

2. Gaidukova E.V., Margaryan V.G., Myakisheva N.V., Pavlov M.R. and Khaustov V.A. Review of methods for effective forecasting of river runoff characteristics in mountain and semi-mountain areas // IOP Conference Series: Earth and Environmental Science, Volume 867, 012006. International Symposium «Earth sciences: history, contemporary issues and prospects» 10 March 2021, Moscow, Russian Federation. doi:10.1088/17551315/867/1/012006

3. Hydrography of ASSR. Yerevan: Academy of Sciences of ASSR, 1981: 177 p. (In Armenian).

4. Kireyeva M.B., Frolova N.L. Present-day special features of the Don river basin rivers spring tide // Water Sector of Russia: Problems, Technologies, Management. 2013. No. 1. Pp. 60-76. (In Russian).

5. Komlev A.M., Melnikova T.N. Water regime of the rivers of the North-West Caucasus. Formation patterns and calculation methods. Perm: PSU, 2008.112 p. (In Russian)

6. Kuzmin V.A., Gavrilov I.S., Sokolova T.A., Timofeev A.Yu. Calculation of the peak flood discharge by the method of integral correction coefficient optimization // Scientific notes of the Russian State Hydrometeorological University, 2010. No. 14, pp. 5-13. (In Russian)

7. Margaryan V.G. The regularities of temporary changes in runoff in the high water period of the Arpa river basin in the context of stable development // Geosphere Research. 2019. № 1. Pp. 44-53. DOI: 10.17223/25421379/9/3. (In Russian). 
8. Margaryan V.G., Gaidukova E.V., Azizyan L.V., Misakyan A.E. Specific Features of the Spring Flood Formation in the Arpa River Basin // Water Sector of Russia: Problems, Technologies, Management. 2021. No. 3. P. 126152. DOI: 10.35567/1999-4508-2021-3-7. (In Russian)

9. Melnikova T.N. Maximum runoff of the spring flood of the rivers of the North-West Caucasus // Vestnik ASU, 2014. Vol. 3 (142). pp. 158-164. (In Russian)

10. Misakyan A.E., Azizyan L.V., Azizyan H.H. Forecast of maximum discharge for the Jermuk observation post on the Arpa river // Modern problems of hydrology, meteorology and climatology in Armenia. Materials of the scientific seminar detieated to World Water and Meteorology Day, March 21-22, 2014. Yerevan: Pub. house «Lusabats», 2014. Pp. 70-73. (In Armenian).

11. Physical Geography of the Armenian SSR. Yerevan. Publishing House of the Academy of Sciences of Armenia. USSR, 470 p. (Armenian).

12. Razmi Ali G.S., Zahmatkesh Z. Non-Stationary Frequency Analysis of Extreme Water Level: Ap-plication of Annual Maximum Series and Peak-over Threshold Approaches. Water Resour. Manag. 2017, 31, $2065-2083$. DOI: $10.1007 / \mathrm{s} 11269-017-1619-4$

13. Savichev O.G. Methodology for calculating the maximum discharge of river waters in the taiga zone of Western Siberia // Izvestia TPU, 2011. V. 318, No. 1, pp. 140-144. (In Russian)

14. Shahinyan, M.V. To the question of the formation of maximum water discharge of the rivers of the Armenian SSR. Proceedings of National Academy of Sciences of Armenia. 1963, 16 (6): 47-56. (In Russian).

15. Shutov A.M. Calculation of the peak flood discharge on small rivers of the Republic of Mordovia // Bulletin of the Mordovian University, 2003. No. 3-4, pp. 106-112. (In Russian)

16. Surface-Water Resources of the USSR. V. 9. Issue. 2. Moscow: Gidrometeoizdat, 1973: 472 p. (In Russian).

17. Zhang X., Feng, B., Zhang, J., Xu Y., Li J., Niu W., Yang Y. The detection of flood characteristics alteration induced by the Danjiangkou reservoir at Han river, China. Water 2021, 13, 496. https://doi.org/10.3390/w13040496 